\title{
Homeless People in West Bengal: A District-Level Study
}

Arindam Roy $^{+*}$ and Dr Giyasuddin Siddique ${ }^{\check{ }}$

\section{Abstract}

The phenomenon of homelessness has often been explained as an obvious result of rapid urbanisation along with the limited housing facility in the urban areas (the destination region), but undoubtedly, it is interlinked with multifaceted issues which have been deeply rooted in the socioeconomic and political set up of the rural areas and small towns (the source region). Ruralurban development disparity, rural-urban migration, poverty, intraregional unequal human development and housing shortage are some of the factors that have intensified the problem of pavement dwelling in urban areas. According to the Census of India (2011), the state of West Bengal holds the 7th position among the states of India with 134040 homeless people. The development disparity between Kolkata and other parts of the state has resulted a definite district-wise spatial distributional pattern of homeless people with the greatest concentration in Kolkata city. The study attempts to probe into the spatio-temporal distribution of homeless population and strives to ascertain the instrumental factors of the phenomenon in a contextual framework with the help of available and acquired data and information. Simple statistical methods- location quotient, Z-score, bi-variate correlation, Sphereman's Rank Correlation Coefficient and Student $t$ test have been used for the analysis. The findings suggest that the less developed districts, as well as the states, surrounded the Kolkata act as the source region that has pushed the destitute community towards the city and compelled them to reside on the footpaths of the city without a roof.

Keywords: Homeless Population, Pavement Dwelling, Poverty, Rural-Urban Migration, Shelterlessness, Spatio-temporal distribution, Urbanisation, West Bengal, India

\footnotetext{
†Junior Research Fellow, Department of Geography, The University of Burdwan, E-mail: a.roy.sc@gmail.com

* Corresponding Author

İProfessor, Department of Geography, The University of Burdwan, E-mail: gsbu2008@gmail.com

(C)2018 Roy and Siddique. This is an Open Access article distributed under the terms of the Creative Commons Attribution License (http://creativecommons.org/licenses/by/2.0), which permits unrestricted use, distribution, and reproduction in any medium, provided the original work is properly cited.
} 


\section{Introduction}

The shelter is one of the necessities of humankind for comprehensive physical, psychological, economic, socio-cultural and intellectual development (Springer, 2000) as 'home' protects from the external adversities and opens multiple windows for selfimprovement. It personifies the ideas of comfort, belonging, identity, security etc. Thus the 'right to shelter' has become intently associated with the issue of human survival and well-being. Adequate housing is recognised as a basic human right by the Universal Declaration of Human Rights (article 25, para1) (UDHR, 2015). However, millions of people of the world in various circumstances are compelled to spend their night under the open sky and continue their lives in front of the public without any security and privacy. Irrespective of the variation of definition, these unfortunate people may be regarded as 'homeless' or 'pavement dwellers' (on the basis of the night time residence). They do not live in 'census houses' (a structure with roof) rather live on the pavement or footpath, under the bridge, flyover, in hume-pipes, places of worship, bus stops, railway stations or yards, parks or any public place in the metros without any 'residence' number or municipal address (Mukherjee, 1975; Census of India, 2011; Homeless Pavement Dwellers Welfare Bill, 2016). They are unable to maintain fixed, regular, safe, secure and adequate domicile (Allred, 2006; Yonge, 2007) and reside at a public or private place not designed for or ordinarily used as a regular sleeping accommodation in the night (Sattar, 2014). This 'poorest of the poor' section of the society is jobless, insolvent, functionless, support less (Lipton and Sabatini, 1984) and even identityless.

Bhattacharya (2012) has argued that homelessness is not only having nowhere to sleep, instead it carries implications of belonging nowhere. So, it is more than rooflessness as it "involves deprivation across a number of different dimensions - physiological (lack of bodily comfort or warmth), emotional (lack of love or joy), territorial (lack of privacy), ontological (lack of rootedness in the world, anomie) and spiritual (lack of hope, lack of purpose)" (Somerville, 2013: 384). They are dwelled in a messy and unhygienic condition, without access to the basic needs; have to compromise with their privacy and often uprooted from their place in the name of development. Along with the pavement dwellers (floating homeless), the 'Situated Homeless' (living at semi-permanent shelter in illegally occupied public land) and the 'Potential Homeless' (live in substandard housing in slum areas with scanty facilities) must be taken into consideration as all such makeshifts are precursor of shelterlessness (Sivramkrishnan and Mondal, 2014). Hence, the growth of slum dwellers can be considered as an indicator of the increase in the magnitude of homelessness (Sattar, 2014).

Probably the phenomenon of homelessness is as old as the history of human settlement. However, it attained a global dimension in the 20th century (Springer, 2000) with the changing socio-political and economic situation of the world. It has become a live issue in the cities, both in the industrialised and technology-rich developed nations as well as developing countries (Ali, 2012). United Nations Habitat Report (2015) has estimated that nearly 100 million people of the world are homeless and another 1.6 billion people 'lacked adequate housing' (UNHR, 2015). In reality, there is no country and virtually no city in the world without the presence of 'sidewalk dwellers' (Mukhopadhyay et al. 1994). However, it is almost impossible to trace the actual magnitude of homelessness as large section of the population remains invisible due to their shifting nature, coupled with the fear of eviction by the civic authorities (Roy Chowdhury, 1999). Many countries have no official concern for homeless people, even to the extent of denying their existence (UNCHS, 2000). At present (2018), the estimated numbers of homeless population in some large cities of the world are as follows (figures are in thousands): Manila 3100, New York 74, Greater Mumbai 60, Los Angeles 58, Jakarta 50, 
Moscow 50, Mexico City46, Buenos Aires 30, Sao Paulo 21, Boston 16, Seattle 12, Budapest 10 and Washington D.C. 9000 (Jegede, 2018).

The multidimensional phenomenon of homelessness is closely associated with ruralurban migration and deeply rooted in the socio-cultural, economic, political, infrastructural set up of the source region of the migrants. Increasing disparity in the development of rural and urban areas generates an inflow of poor, impoverished, unemployed people into the city that enhances the complexities of the problem of homelessness in the urban areas. This study endeavours to throw light on the spatiotemporal dynamics of homelessness in West Bengal along with the instrumental forces and factors behind the issue. The article begins with a review of literature. This is followed by a background to the study area. Thereafter, the article discusses the methodological issues, and the findings of the study.

\section{Review of Literature}

The gathering of homeless people in the streets of almost every urban centre of the world has drawn the attention of the administrators and academicians. Several scholars of different disciplines like Patel (1990), Baker et al. (1997), Springer (2000), Tribhuvan and Andreassen (2003),Tipple and Speak (2004), Vázquez et al. (2005), Koehlmoos et al. (2009), Patra and Anand (2008), Morrow (2010), Nooe and Patterson (2010), Ali (2012 and 2014), Somerville (2013), Mostowska (2013), Ryabchuk (2014), Busch-Geertsema et al. (2016) have addressed the issue from different philosophical perspectives, socioeconomic and political contexts. Despite the paucity of proper documented accounts, the homeless population of Kolkata metropolis has been broadly studied by different scholars (Das, 2013; Mustaquim and Ismail, 2013; Chaudhuri, 2013; Adhikari, 2014; Ghosh, 2014; Mukherjee, 2014; Shivramkrishnan and Mondal, 2014; Dey and Majumdar, 2015; Bagchi, 2016; Basu, 2016; Kar, 2016). Bela Bhattacharya (1996) in her book titled "Slums and Pavement Dwellers of
Kolkata Metropolis" presents a detailed ethnographic enquiry concerning the sociodemographic structure, living conditions, economic and occupational characteristics, social associations and relations of the homeless people. In "Homeless Pavement Dwellers: A Case Study of their Social Awareness in Kolkata from Human Rights Perspective" (2012) she has presented an extensive disquisition over the issue from the human rights perspective. In their comprehensive study, Jagannathan and Halder (1988 and 1989) also have discussed the issues with particular reference to family characteristics, occupational patterns, income status, rural-urban linkage and mobility. Almost all the previous studies have predominantly stressed upon the socioeconomic and demographic status of the community in Kolkata, whereas, the state level scenario is invariably overlooked or somehow denied. The causal factors, in many cases, do not adequately explain and hence become uncertain, murky. Therefore, the present study focuses on the district level analysis of homelessness in West Bengal and strives to interlink the responsible factors with the issue.

\section{The Study Area}

West Bengal has been taken as the unit of study. The state $\left(21^{\circ} 30^{\prime} \mathrm{N}\right.$ to $27^{\circ} 14^{\prime} \mathrm{N}, 86^{\circ} 30^{\prime} \mathrm{E}$ to $89^{\circ} 53^{\prime} \mathrm{E}$ ) is one of the eastern states of India with a total geographical area of $88,752 \mathrm{sq} . \mathrm{km}$. It accommodates nearly 91.3 million (rural $68.11 \%$ and urban $31.89 \%$ ) people with a population density of 1029/ sq. km (Census, 2011). It is the 14th largest state in terms of area (occupies $2 \%$ area of the country) and the 4th largest state in terms of population (comprises $7.6 \%$ of the total population). The state has 19 districts, divided into three administrative divisions (2011). The capital city of the state is Kolkata (the third largest city of India). Bangladesh and Assam border the state in the east; Bihar, Jharkhand, and Odisha states on the west; Nepal, Bhutan and Sikkim on the north and the Bay of Bengal in the south (Figure 1). 


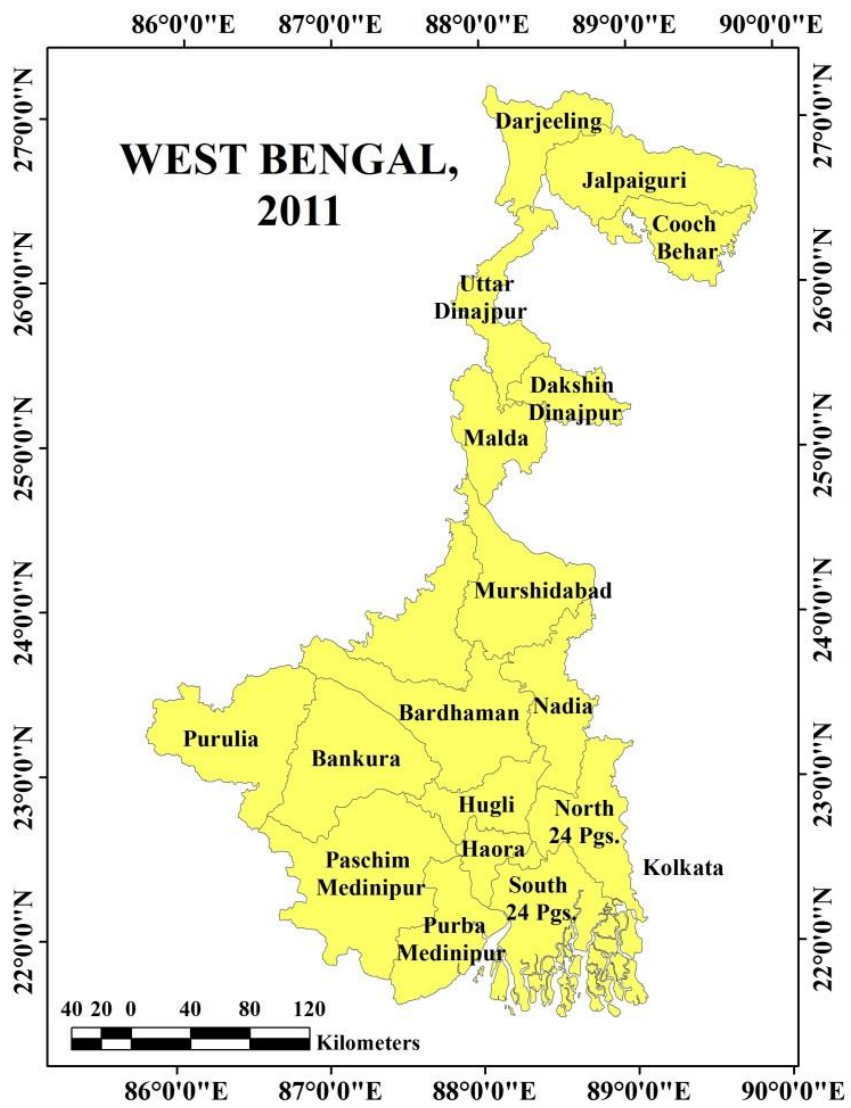

Figure 1: Location Map of the Study Area

Source: Prepared by the Authors

\section{Objectives and Methodology}

The principal objectives of the study are:

- to present a detailed account of the spatiotemporal distribution of the homeless population in the districts of West Bengal;

- to identify the source areas of homeless people in the area and investigate the causes of homelessness in the source region as well as the destination region

The major part of the study has been framed on the basis of available secondary data and information collected from various sources like the Census of India (1961- 2011), District Statistical Handbooks, District Human
Development Report, 2010-11, Statistical Abstract of West Bengal (2013 and 2015) and West Bengal Development Report, 2010. Relevant literature has been intensively reviewed to develop a conceptual framework for the study and also to identify the key factors responsible for homelessness. The collected information has been analysed with the help of simple statistical techniques to examine the interrelationships among the various causal factors. Bi-variate analysis has been used in this context. Z-score is computed to assess the spatial pattern of distribution of homeless population among the states and districts using the formula:

$$
\text { Z-Score }=\frac{X \text { - Mean }}{\text { S.D. }}
$$

Location quotient has been calculated to detect the degree of concentration of homeless population using the formula:

$$
\mathrm{LQ}=\frac{\mathrm{e}_{\mathrm{i}} / \mathrm{e}}{\mathrm{E}_{\mathrm{i}} / \mathrm{E}}
$$

Where, $\mathrm{e}_{\mathrm{i}}$ total homeless population in each district, $\mathrm{e}=$ total population in the district, $\mathrm{E} \mathrm{i}=$ total homeless population of the state and $\mathrm{E}=$ total population of the state. 
Concurrently, a primary survey of 203 homeless households (having a population of 632; 460 males and 172 females) has been taken from different parts of the Kolkata city (especially in the Sealdah rail station and Barrabazar area, etc.) during March-June 2017 and 2018 with a semi-structured questionnaire to acquire the primary data. Purposive random sampling technique is used to select the respondents. The conclusion is drawn through a review of vast literature and analysis of collected data. The significant findings have been explained through vivid and informative description along with various maps and cartographic diagrams. The following section discusses the homelessness landscape at the national level.

\section{Homelessness at National Level: A State Level Analysis}

Though the Article 21 ('Right to Life and Personal Liberty') of the Indian Constitution encompasses the 'Right to Shelter' by signifying 'shelter' as the fundamental necessity for a happy and healthy life with human dignity; and free from any exploitation. However, nearly 1.77 million people in India (comprising $0.15 \%$ of the country's total population that is 1210.19 million) have lived without any shelter, keeping themselves off from all safeguards of human rights. Of them, $52.9 \%$ are found in the urban areas whereas $47.1 \%$ are found in the rural areas. Nearly, 0.94 million people in the urban areas $10.25 \%$ of the total urban population of 377.11 million) and 0.83 million ( $0.1 \%$ of the total rural population of 833.08 million) people in rural areas live without any shelter (Census, 2011). Therefore, even after six decades of independence, it is one of the biggest challenges in front of the policymakers and the administrators of India. Notwithstanding, the number of the total homeless population has been decreased since 1981 in response to the reduction of rural homelessness, but the urban homelessness has recorded a continuous increment since 1961 (Figure 2). The country shows $8.76 \%$ decrease in the homeless population during 2001-2011 (Census, 2011). With rapid urbanisation (growth rate of $2.76 \%$ per annum during 20012011), the urban areas have reported a $20.51 \%$ increase in homeless population during the last decade. It clearly indicates the interrelationships between the phenomena of urbanisation and homelessness. On the contrary, the rural areas show $28.34 \%$ decline in homeless population during the stipulated period as the consequence of the shift of the rural poor towards the urban areas that increments the volume of the homeless people in the cities (Sattar, 2014).

Generally, the bigger states in terms of size and population comprise the large share of the homeless population. Nearly $65.3 \%$ of the homeless population is spread over six states of India: Uttar Pradesh, Maharashtra, Rajasthan, Madhya Pradesh, Gujarat and Andhra Pradesh (Kumuda, 2014) (Figure 3). Uttar Pradesh (72452) has the highest concentration of homeless population followed by Maharashtra (57480), Andhra Pradesh (42812), Madhya Pradesh (37822), Rajasthan (37341) and Gujarat (144306) (Census of India, 2011).

The z-score maps clearly show the temporal change in the distribution of the homeless population over the states from 2001 to 2011 (Figure 4). Overall, the homeless population has decreased in the majority states of the country during the last decade. The states like Maharashtra, Gujarat, Kerala, Karnataka and Tamil Nadu show a gradual decrease in homeless population over the decade, whereas, the states like Tripura, Jammu and Kashmir, Manipur, Jharkhand, Rajasthan and Uttar Pradesh have recorded a significant increase in shelterless population, especially in urban areas. The problem now has achieved a critical dimension in the megacities of India with steady urban growth during the last few decades.

Among the megacities, Kolkata $(69,798)$ shows highest concentration of homeless population followed by Mumbai $(57,416)$, Delhi $(40,120)$, Hyderabad $(31,476)$, Chennai $(16,482)$, Bengaluru (13,907), Ahmedabad $(11,293)$ and Pune $(3,340)$ (Census of India, 2011). 


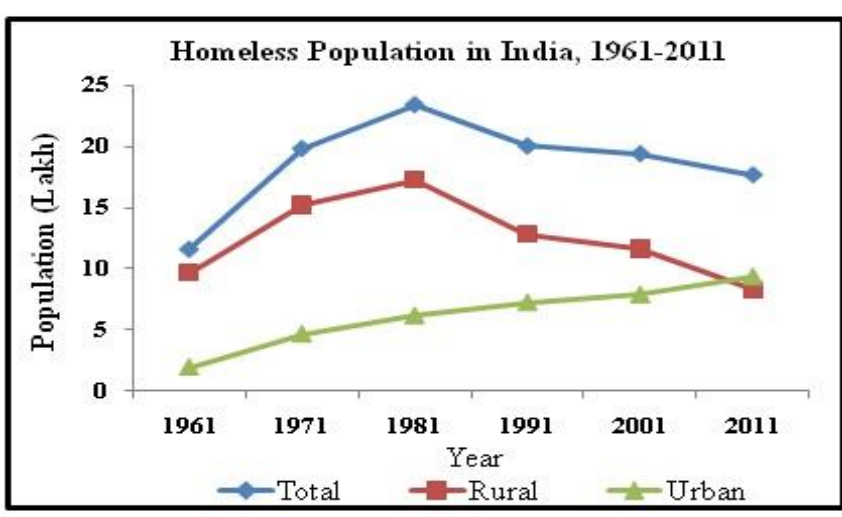

Figure 2: Homeless Population in India, 19612011

Source: Census of India, 1961-2011

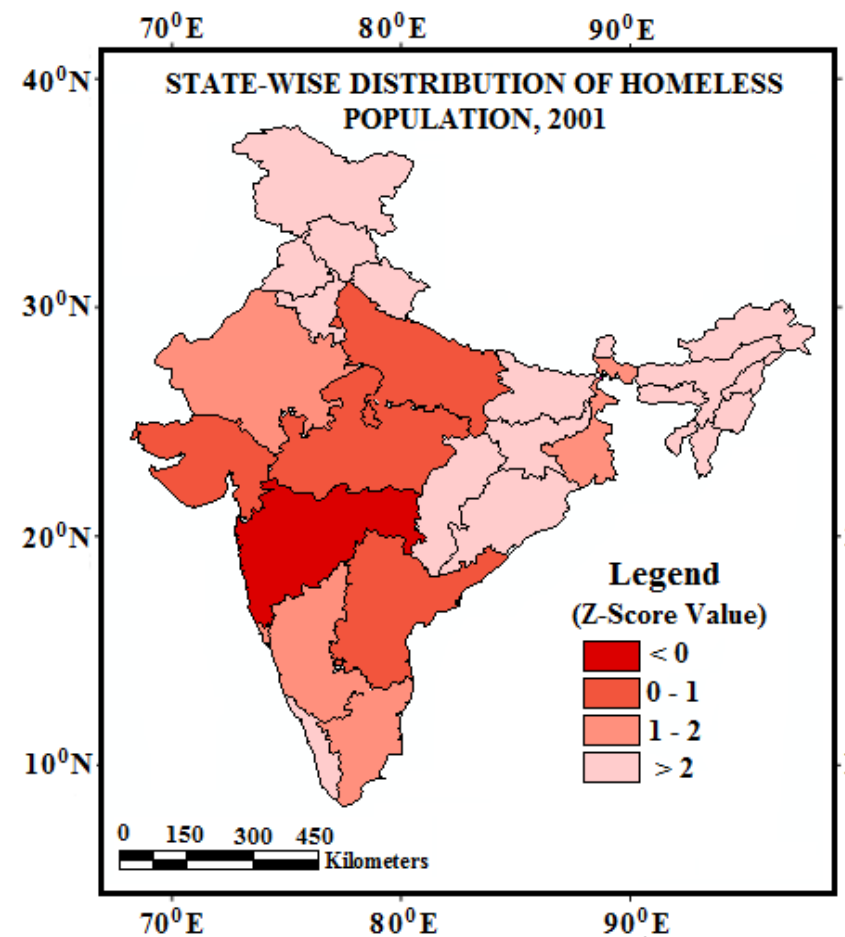

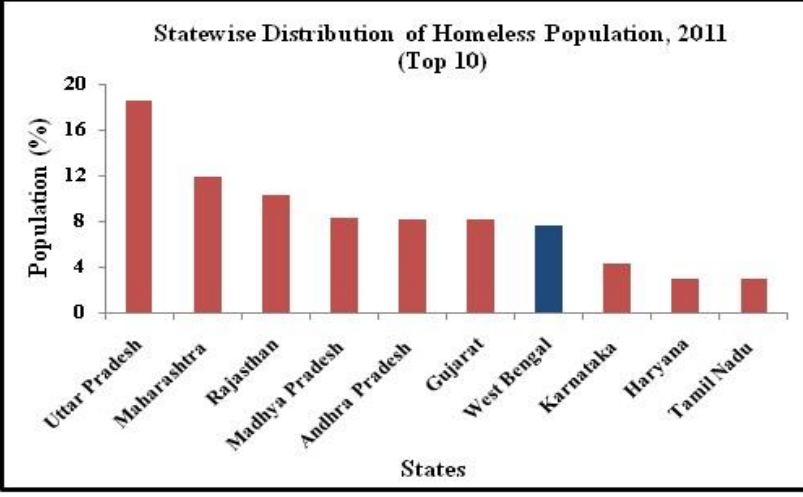

Figure 3: State-wise Distribution of Homeless Population, 2011 (Top 10)

Source: Census of India, 2011

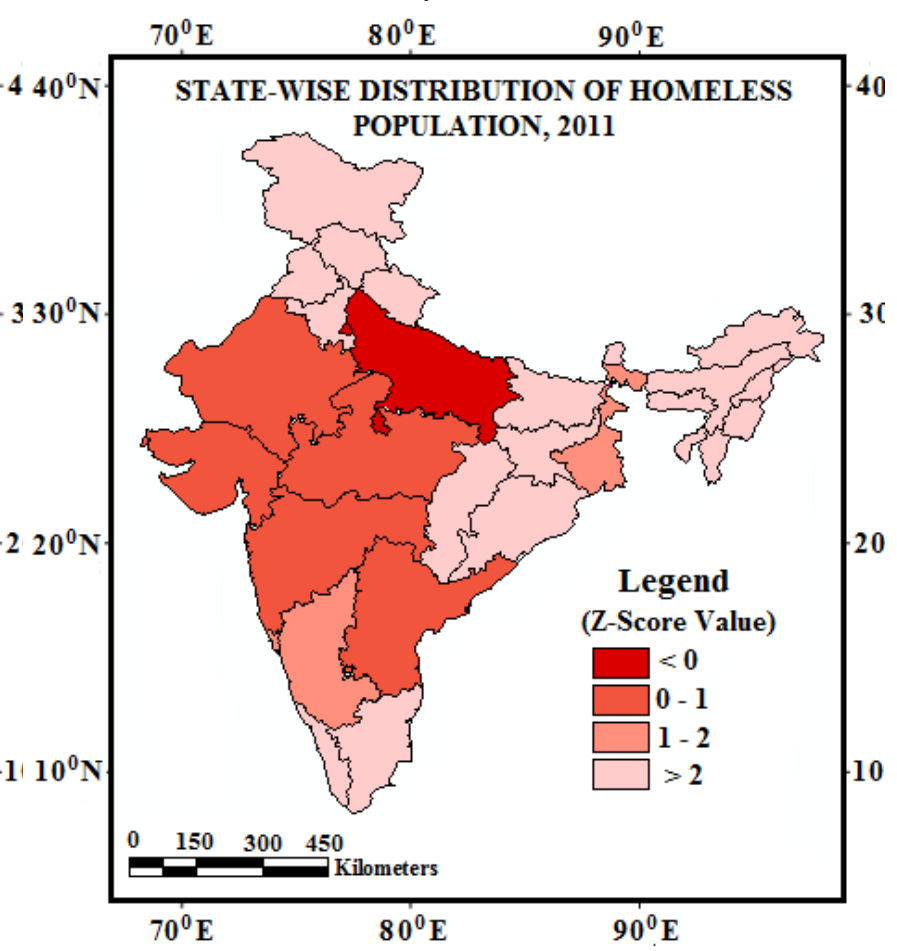

Figure 4: State-wise Distribution of Homeless Population, 2001 and 2011

Data Source: Census of India, 2011 and 2011 (Compiled by the Authors)

Homelessness in West Bengal: A District Level Scenario

West Bengal, with 134040 houseless people (above the national average of 52148), comprises $7.78 \%$ of the nation's total homeless population. $68.52 \%$ homeless population in the state are males while, $31.48 \%$ are females. Kolkata, the smallest district and the largest urban centre of the state has recorded the highest number of pavement dwellers. The city has accommodated nearly 12.250 houseless households with a total houseless population of 69798 in 2011 . It comprises $52.07 \%$ of the state's total followed by North 24 Parganas (6.81\%), Uttar Dinajpur (6.16\%), Haora (4.25\%),
South 24 Parganas (4.06\%) and Bardhaman (3.77\%). District Cooch Behar has recorded lowest concentration of houseless population (0.52\%), followed by Dakshin Dinajpur (0.65\%), Darjeeling (1.16\%), Purulia (1.18\%) and Purba Medinipur (1.28\%) (Census, 2011) (Figure 5).As stated above, Kolkata has recorded the highest concentration of homeless population (LQ value: 10.57), followed by Uttar Dinajpur with moderate concentration (LQ value $1-2$ ). The districts like Darjeeling, Malda, Birbhum, Haora and North 24 Parganas, however, show a relatively less concentration. Other districts represent an insignificant concentration of homeless population $(<0.50$ ) (Figure 6). Z-score 
map traces the spatial pattern of distribution of the homeless population. (Figure 7) Naturally, Kolkata shows the highest z- score value followed by North 24 Parganas and Uttar Dinajpur(z-score value : $0-0.2)$. On the contrary, Cooch Behar and Dakshin Dinajpur show lowest $z$-score values $(<-0.4)$. The maximum number of districts of the state shows low to moderate $z$-score value.

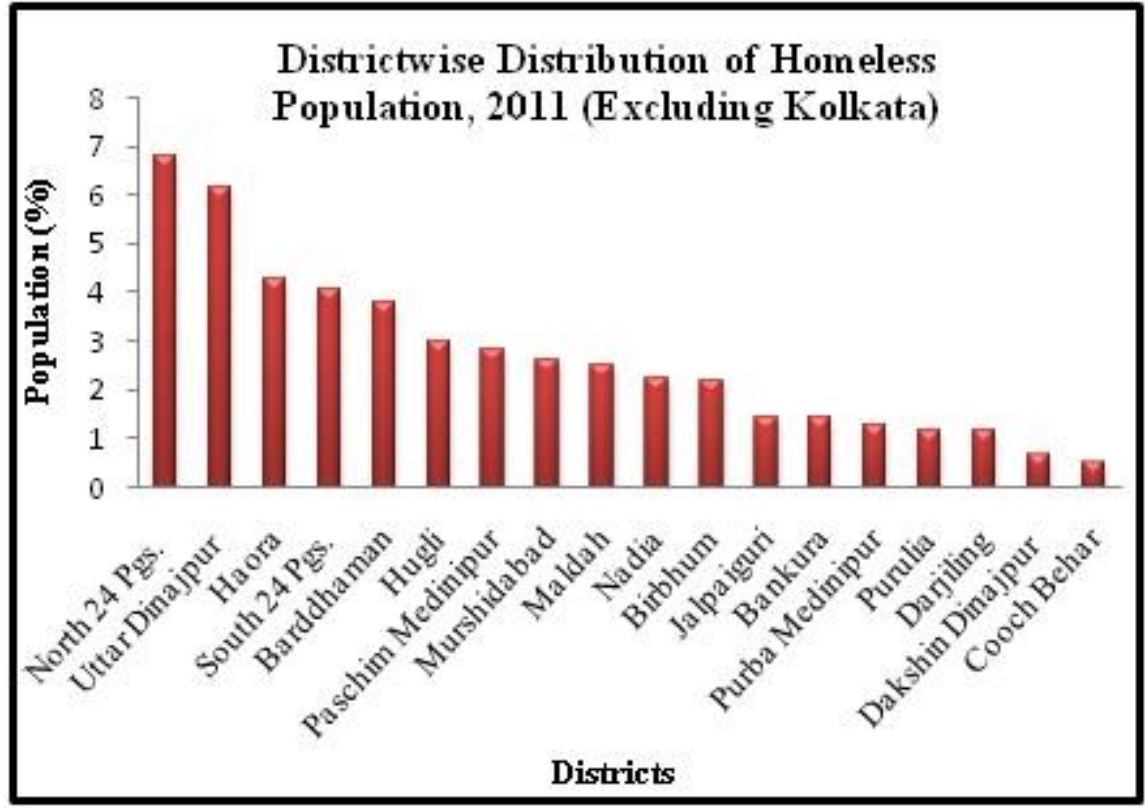

Figure 5: District-wise Distribution of Homeless Population, 2011 (excluding Kolkata) Source: Census of India, 2011

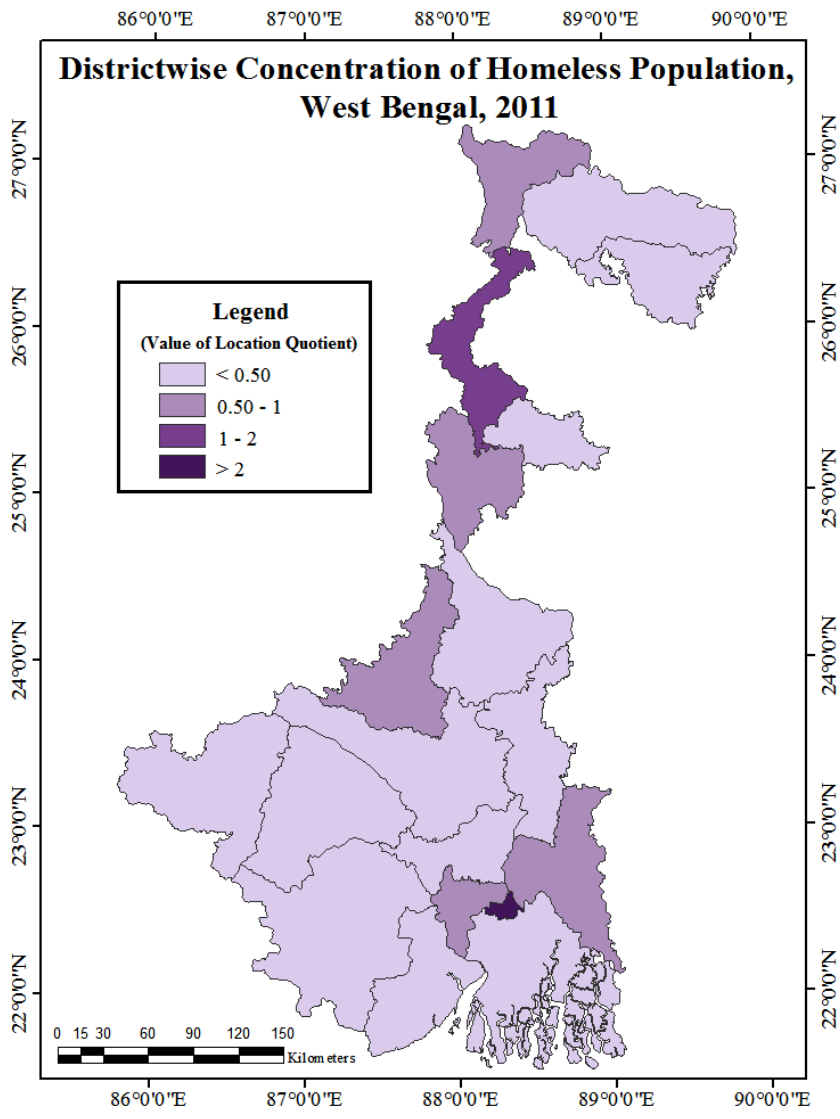

Figure 6

Data Source: Census of India, 2011 (Compiled by the Authors) 


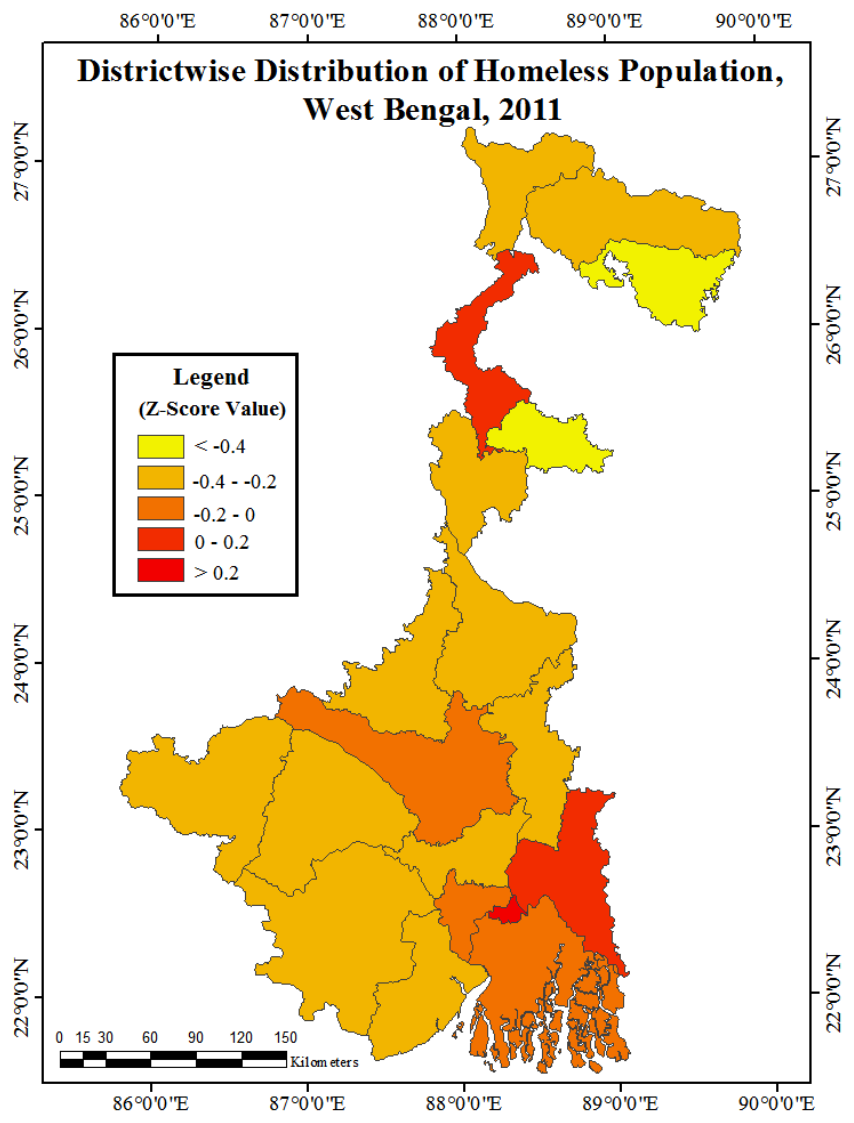

Figure 7

Data Source: Census of India, 2011 (Compiled by the Authors)

Distribution of Rural and Urban Homelessness during 2001-2011. The rural homelessness

Homeless people are unevenly spread over the state with maximum concentration in the urban areas compared to its rural counterparts. Nearly $21.69 \%$ shelterless population are found in the bucolic part of the state, whereas, $78.31 \%$ of them have reside in the footpaths of the large towns (Figure 8 ). In case of rural homelessness, South 24 Parganas shows the highest concentration; followed by North 24 Parganas, Murshidabad, Bankura, Paschim Medinipur, Birbhum and Bardhaman with moderate concentration (Figure 9). In case of urban homelessness, undoubtedly the state's capital has recorded the highest (Z-Score value 4.09). North 24 Parganas and Uttar Dinajpur have recorded moderate concentration, whereas, rest of the districts record an inconsiderable concentration of urban homeless people (Figure 10).

\section{District-Wise Decadal Growth Rate of Homelessness, 2001-2011}

The state has experienced a moderate rate of increase $(21.26 \%)$ in homeless population shows a comparatively lesser rate of increase of $15.59 \%$, whereas the urban homelessness has increased up to $47.38 \%$ during the same period. Four districts, namely Darjeeling ($54.46 \%)$, Jalpaiguri (-27.04\%), Cooch Behar ($19.35 \%)$ and Hugli (-1.83\%) have reported negative growth in homeless population during 2001 to 2011. Except for these four districts, all other districts show a positive growth rate. Malda (273.79\%) shows the highest growth in homeless population followed by Bankura (259.81), South 24 Parganas (192.10\%), Nadia (152.09\%), Uttar Dinajpur (133.67\%) and Birbhum (129.32\%) (Figure 11). Darjeeling district has experienced highest negative growth rate both in rural and urban homelessness $\quad(-53.96 \%$ and $-54.9 \%$ respectively), whereas, Bankura has recorded highest positive growth $(270.37 \%)$ in rural homelessness and Malda shows highest growth rate in urban homelessness (1940\%). Acute poverty and failure of Govt. housing policy seems to be the prime causes behind such massive increase in rural homelessness in 
Bankura. On the other hand, high increase of urban homeless people in Malda District is the outcome of the massive urbanisation (129.07\% growth in urban population in 2001-20111) caused by the incoming of rural uprooted people from the river-bank erosion affected areas. The capital city Kolkata shows 3.14\% increase in urban homelessness (Table 1).

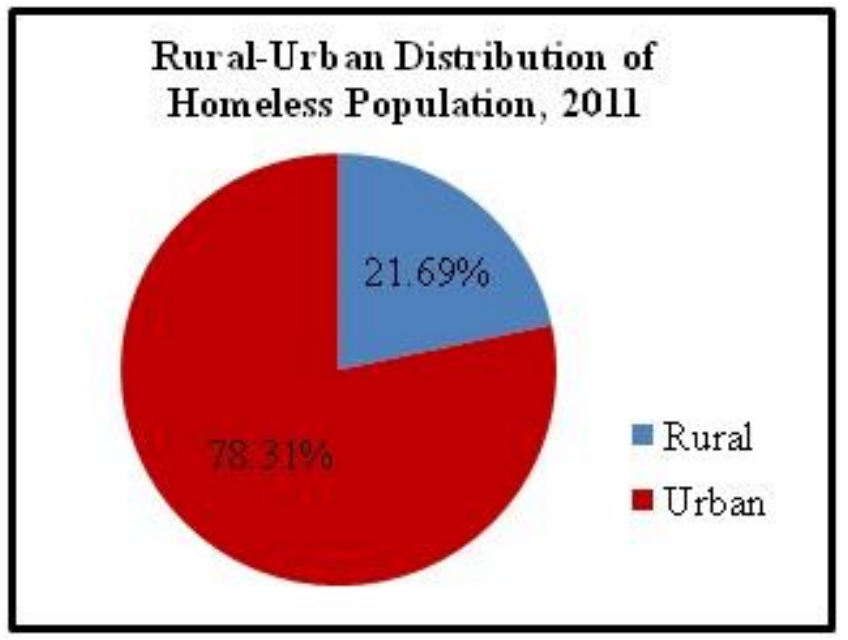

Figure 8

Data Source: Census of India, 2011

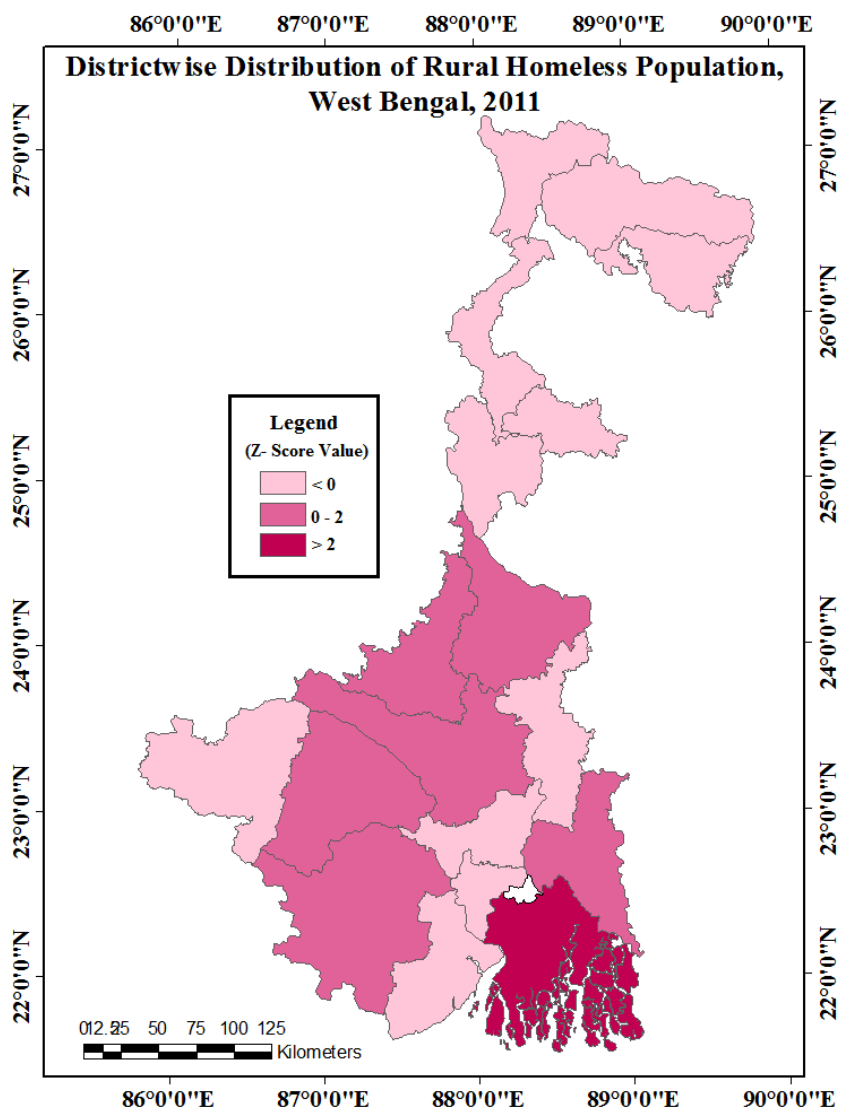

Figure 9

Data Source: Census of India, 2011 


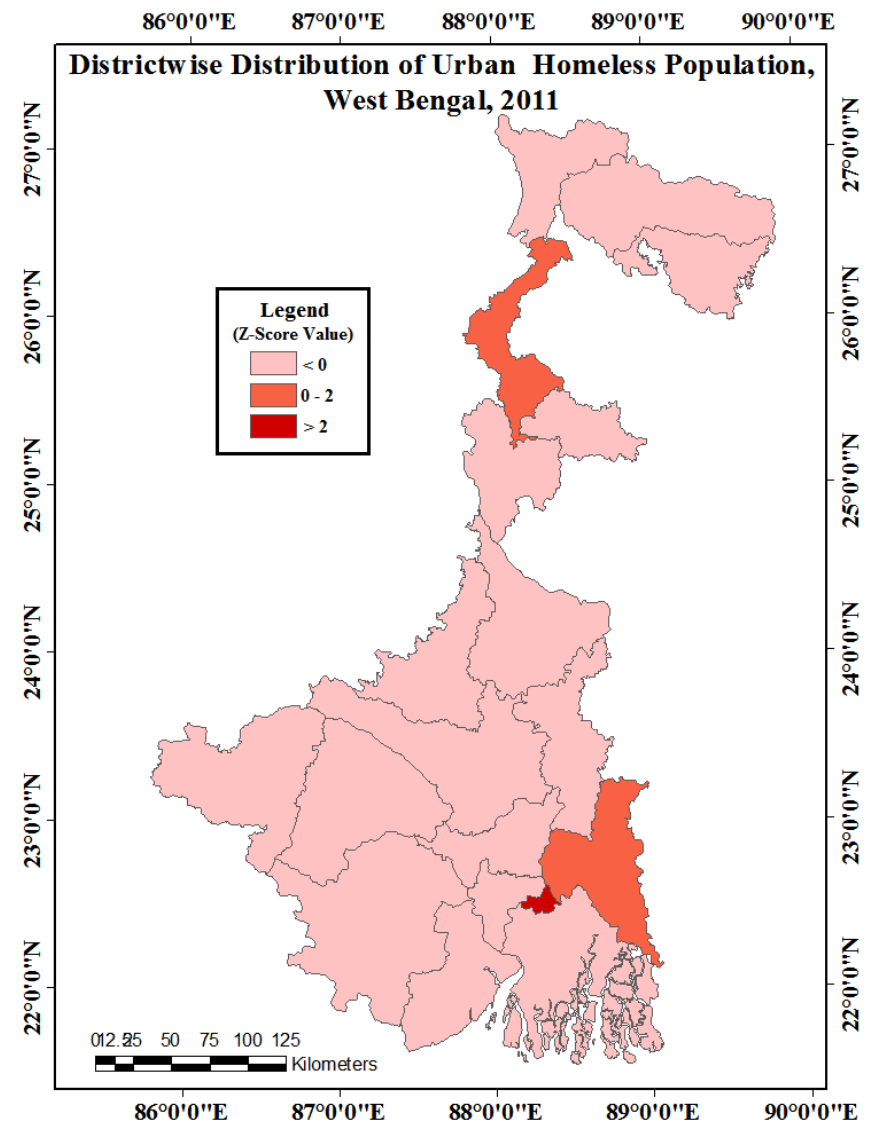

Figure 10

Data Source: Census of India, 2011

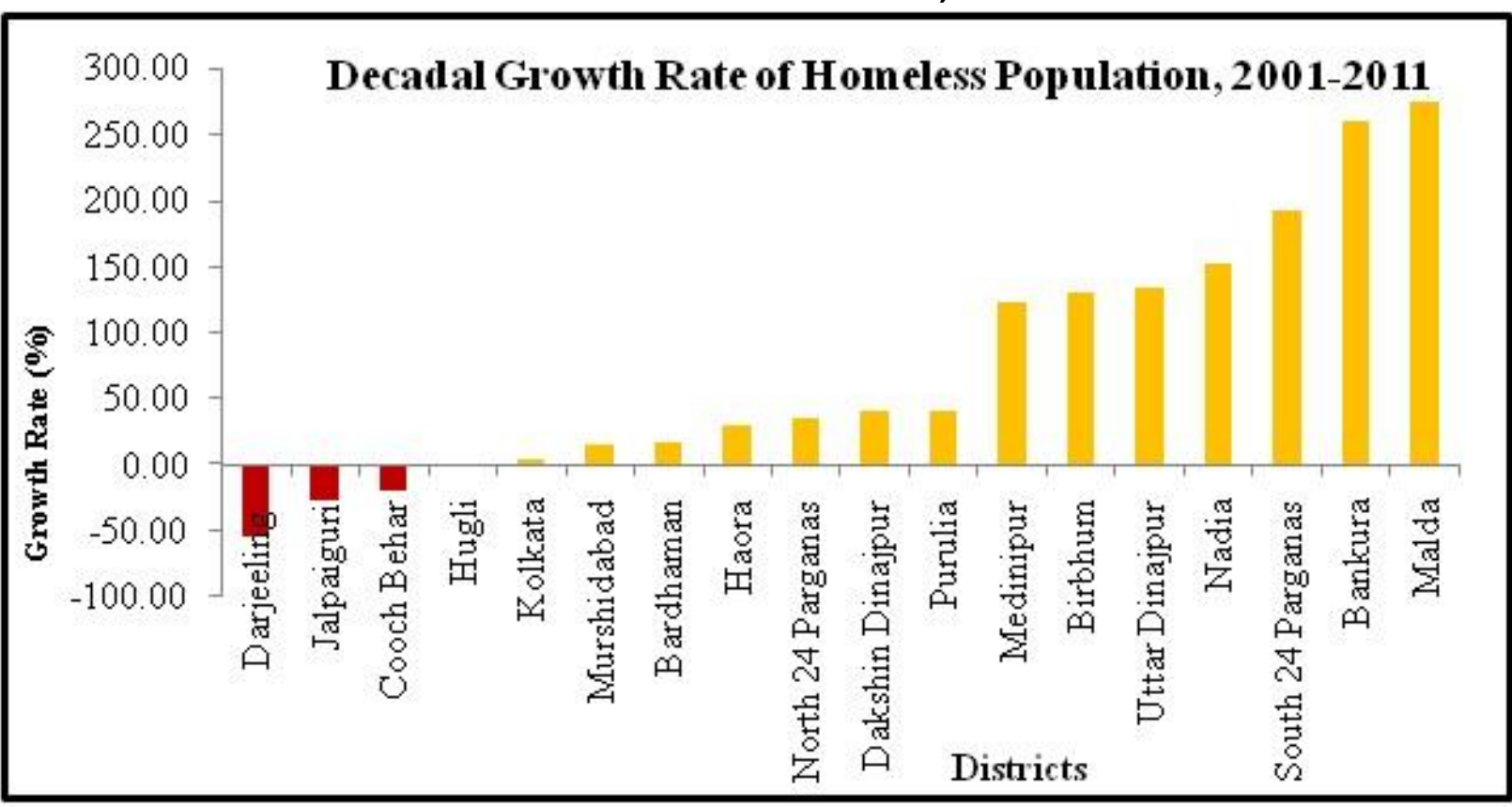

Figure 11

Data Source: Census of India, 2001-2011, Computed by the Authors 
Table1: District wise Decadal Growth Rate in Rural and Urban Homelessness, 2001-2011

\begin{tabular}{lrrlrr} 
Name of the District & \multicolumn{1}{c}{ Rural (\%) } & Urban (\%) & Name of the District & Rural (\%) & Urban (\%) \\
\hline Darjeeling & -53.96 & -54.9 & Malda & 38.51 & $1940)$ \\
\hline Hugli & -32.19 & 23.58 & Purulia & 58.66 & -0.9 \\
\hline Cooch Behar & -25.68 & 0.48 & North 24 Parganas & 70.45 & 26.31 \\
\hline Uttar Dinajpur & -13.39 & 191.21 & Haora & 86.08 & 17.02 \\
\hline Bardhaman & -7.8 & 49.61 & Dakshin Dinajpur & 108.12 & -12.14 \\
\hline Nadia & -1.48 & 415.51 & Medinipur & 151.53 & 56.07 \\
\hline Kolkata & 0 & 3.14 & Birbhum & 164.86 & 20.45 \\
\hline Jalpaiguri & 10.48 & -44.85 & South 24 Parganas & 166.82 & 296.42 \\
\hline Murshidabad & 14.57 & 18.55 & Bankura & $270.37)$ & 196.05
\end{tabular}

Sources: Census of India, 2001 and 2011; Compiled by the Authors

\section{Discussion}

The causal factors of homelessness have been widely perusal and evaluated by scholars of different disciplines (Bhattacharya, 2012). Most of the previous studies have advocated the difficulties of establishing any linear relationships between one specific factor and homelessness due to the multifaceted and complex character of the phenomenon where several overlapping risk factors influence the phenomenon. In reality, the correlation between each factor and homelessness is typically intricate and can be understood only in the context of people's life histories (Somerville, 2013). The significance of the elements has changed drastically with the changing space, time as well as socio-economic and political perspectives of the society. Historically, the study of homelessness in the western world shows a typical switch in its approach over time. Gowan (2010) has identified three principal and popular historical types of explanation of homelessness as:

- Sin Talk: (prevailed until the 1960s) the homeless people were liable for their condition. They are compelled to live in a shabby environment due to their personal indiscretion like addiction to drug and alcohol, general unruliness and irresponsibility, etc.

- System Talk: (during the 1960s to 1980s) the dilemma of homelessness was ascribed to the structural factors such as lack of jobs, income and affordable housing.
- Sick Talk: (from the 1980s to the present day) Homelessness is associated with individual pathological issues (like mental health problems, personality disorders, disabilities and vulnerabilities of various kinds).

A 'new orthodoxy' (May, 2000; Pleace, 2000) has been transpired at the beginning in the 1980s (Brandon et al. 1980) in which homelessness is explained in terms of a specific amalgamation of structural factors and individual vulnerabilities. 'Structural' factors create the environment within which homelessness occurs, and 'individual' factors conclude the likelihood of becoming homeless in those conditions (Fitzpatrick et al. 2000; Pleace, 2000).

\section{Causes of Rural Homelessness}

Although homelessness is a common concern both in rural and urban areas (Morrow, 2010) the rural homelessness almost remain unnoticed in policy debates as well as in the study of the academicians due to distinguishing hidden nature accompanied with the migrating trend of rural poor towards the urban centres (UNCHS, 2000). The rural homelessness remains veiled as the rural poor often cope with the miserable condition through temporary makeshift arrangements (Wardhaugh, 2012; Sattar, 2014).

Dupont et al. (2000) have asserted the interconnection of rural and urban homelessness as rural poverty pushes the male members of households to migrate to urban areas in search of job or income. Consequently, 
the rural homelessness has been reduced and the occurrence of homelessness in urban areas has increased its magnitude. The migrated persons send money to their family residing in the native village in poor and insecure circumstances. Poverty, landlessness and unemployment are the prime economic factors of rural homelessness (UNCHS, 2000; Wardhaugh, 2012). Disasters, either natural or human-made, are other critical factors of rural homelessness (UNCHS, 2000). For example, in the year 2009, 21782 rural houses fully collapsed, and 44849 houses were partially damaged in 24 Parganas (North and South) by cyclone Aila (Situational Report, 2009). Up to 2005, more than 700,000 people of Malda and Murshidabad districts have been displaced due to bank erosion of the river Ganga (Khatun et al. 2018). Such massive displacement by natural calamities generally increases the quantity of rural homeless people. It has been estimated that annually, around 30 million people are affected and 2.34 million houses are being lost by disasters (Chauhan, 2009). Natural calamities like cyclones, floods and river bank erosion, mostly evident in some districts like South 24 Parganas, Murshidabad and Malda, have not only destroyed the domicile of the rural poor but also affected their source of livelihood. Physical loss of land or alteration of its nature compelled them to leave their habitat of the ancestors as assurance of continuing the life system is denied and rush towards the nearby urban areas (especially towards Kolkata) in destined condition because in this circumstance, begging in the streets is acceptable to these groups rather than starving for long days.

Displacement by any developmental activity raises the immensity of homelessness in rural areas (Tripathi, 2017). A Reference Note (No. 30/RN/Ref./December/2013) of the Lok Sabha (2013) has reported that nearly 6.9 million people have been displaced in West Bengal during 1947-2004 due to various development activities such as mining operations, construction of dams, industries and transport routes. Fernandes et al. (2006) has reported that mining activities have displaced nearly 418061 people during 1960-2000in West Bengal. 11800 people have been displaced by the establishment of Durgapur Steel Plant (Government of India, 1985) and 93,900 persons have been displaced by the construction of Maithan and Panchet dam in West Bengal and Jharkhand (Government of India, 1985). Such significant displacement events have incremented the number of rural homeless people, who generally move towards the nearby urban centres and has enlarged the volume of urban homelessness.

It has been estimated that only $25.48 \%$ of displaced persons were rehabilitated in the national level during 1947-1989 (Fernandes and Rao, 1989; Bharati, 1999) (Table 2). From 1947 to 2000 , nearly 47 lakh acres of land has been acquired for development projects that have affected 70 lakh persons in West Bengal. Of them, 36 lakh were displaced persons (DP), and 34 lakh were deprived of livelihood without being physically relocated projected affected persons (PAP) (Fernandes, 2007). The state has resettled only $9 \%$ of the displaced population (Fernandes et al. 2006). The vast percentage of the non-settled population generally has positively influenced the volume of homeless people.

Besides, some political forces (local political pressure, political conflict, unresponsiveness etc.) and socio-cultural causes (ethnic isolation, social unrest/communal riots, eviction, social marginalisation) may also have caused widespread displacement and long-term homelessness (Seshadri, 2008). This is evident in developing countries but not widely discussed due to the inadequacy of data or information and socio-political complexities (UNCHS, 2000). 
Table 2: Persons Displaced and Rehabilitated by Various Projects in India since 1947

\begin{tabular}{cccccc} 
Type of Project & $\begin{array}{c}\text { Number of } \\
\text { Displaced } \\
\text { persons }\end{array}$ & $\begin{array}{c}\text { Number of } \\
\text { Rehabilitated } \\
\text { persons }\end{array}$ & $\begin{array}{c}\text { Rehabilitation } \\
(\%)\end{array}$ & Backlog & $\begin{array}{c}\text { Backlog } \\
(\%)\end{array}$ \\
\hline Coal and Other Mines & 1700000 & 450000 & 26.47 & 1250000 & 73.53 \\
\hline Dams and Canals & 11000000 & 2750000 & 25 & 8250000 & 75 \\
\hline Industries & 1000000 & 300000 & 30 & 700000 & 70 \\
\hline Others & 1200000 & 300000 & 25 & 450000 & 75 \\
\hline Total & 15500000 & 3950000 & 25.48 & 11550000 & 74.52
\end{tabular}

Sources: Fernandes and Rao, 1989; Bharati, 1999

\section{Causes of Urban Homelessness}

The urban dimension of homelessness is the most visible and prominent phenomenon. In a simple framework, homelessness of urban areas may be addressed as an outcome of exponential urbanisation coupled with the existing gap between the demand and supply of housing units. However, in reality, the pathway towards homelessness has been characterised with many complexes, multifaceted and overlapping interconnected issues that need further investigation for complete understanding of the role of factors and their connections with homelessness (Somerville, 2013). Nooe and Patterson (2010) have developed an ecological model of homelessness encompassing almost all the biopsychosocial risk factors (both individual and structural factors) as well as the social and individual outcomes. The model recognises the complexities of the interplay between the individual factors and social factors on different systems levels.

Various scholars like Speak (2004), Warnes and Crane (2006), Nooe and Patterson, (2010), Heinze et al. (2012) have identified different responsible causes of urban homelessness. The prime structural factors of urban homelessness are unemployment, housing costs and availability, deinstitutionalisation, unavailability of health care, discrimination, low wage and income. However, the individual factors attributing to homelessness could be age, sexual abuse, family conflict, domestic violence, incarceration, physical and mental illness, maltreatment, divorce and separation, single motherhood, etc. (SPARC 1985; Ullah et al.
1999; Fitzpatrick et al. 2000; Bhattacharya, 2012; Ryabchuk, 2014; Johnsen and Watts, 2014, BBC News).

It has been revealed from the primary survey (2017-18) that $89.72 \%$ of the respondents came to the city for economic objectives. $78.33 \%$ of them does not possess any land in their native places, whereas, $58.62 \%$ has reported their inability to earn sufficient to sustain life in their area in their native place. Rest $21.67 \%$ respondents possess small landed properties in their villages, which is insufficient to meet the daily needs of their family. So, the male member of the family had to shift to Kolkata for working at least as labour. 26.39\% of respondent households (mainly intra-district migrants) have lost their houses and agrarian land due to some natural calamities. As a result, they have rushed towards the city of Kolkata to take shelter in the streets.

The survey has also pointed out that $11.33 \%$ of the respondents have shifted towards the city for non-economic purposes. $8.37 \%$ of the families have been led by women, either a widow or abandoned by husband and have shifted to the city for feeding their children. Another $2.96 \%$ homeless women have reported that they have left their houses to get rid of domestic violence and $1.48 \%$ pavement dwelling women come to the city through trafficking. 4 young boys (1.97\%) lived in the station premises and engaged in rag picking reported that they were orphans and had come to the city to get rid of the torture of their local guardians.

Urbanisation, associated with rural-urban migration is one of the prime causes of urban 
homelessness. Bhattacharya (2012) has pointed out that uncontrolled urbanisation in the Third World has intensified the gathering of destitute people on the street of the urban centres. The cities/towns of West Bengal are not exceptions (Table 3).

The state was one of the most urbanised states of India before independence (Ghosh and Chakma, 2014) and currently, 31.87\% people live in urban areas which is marginally higher than the national average (31.16\%) (Census of India, 2011) (Figure 12). The urbanisation pattern of West Bengal is characterised with 'urban primacy,' that is the excessive concentration of the urban population in and around Kolkata with the very low level of urbanisation in the interior districts (Giri, 1998;
Chakraborty et al. 2015). The city of Kolkata (formerly Calcutta) has been exponentially developed as the administrative core and a leading economic hub of eastern India by the colonial rulers as well as the administrators in the post-independence period. The other parts of the state remain backward and neglected. Thus improper regional planning guided by wrong administrative decisions has formed an imbalanced regional development. Consequently, a wide disparity in the socioeconomic and infrastructural development has been created between KMC (Kolkata Municipal Corporation) and its adjoining areas and the rest of the bucolic parts of the state (Anisujjaman, 2015).

\section{Table 3: Top Ten Urban Centers with Homeless Population, West Bengal, 2011}

SI.No. Name of the Urban Centre Homeless Population Percentage to Total Homeless People

\begin{tabular}{lccc}
\hline 1 & Kolkata & 69798 & 52.07 \\
\hline 2 & Raiganj & 7067 & 5.27 \\
\hline 3 & Haora & 2958 & 2.21 \\
\hline 4 & English Bazar & 2087 & 1.56 \\
\hline 5 & Bhatpara & 1163 & 0.87 \\
\hline 6 & Bidhannagar & 1138 & 0.85 \\
\hline 7 & Nabadwip & 1082 & 0.81 \\
\hline 8 & Bardhaman & 862 & 0.64 \\
\hline 9 & Siliguri & 809 & 0.60 \\
\hline 10 & Naihati & 799 & 0.60
\end{tabular}

Source: Census of India, 2011

The overwhelming role of the primate city along with the increasing development disparity has generated a flow of migrants towards the city (Anisujjaman, 2015).A chunk of poor people from the less developed neighbouring states like Bihar, Jharkhand, etc. have come to the city as cheap labours that have escalated the homeless scenario. In addition, the massive influx of refugees from the eastern part of Bengal (now Bangladesh) contributed to urban concentration immediately before the independence (Giri, 1998). The state, especially the city of Kolkata has witnessed an immense flow of cross-border immigrants (especially the people belonging to the Hindu religion) over four decades for its locational proximity to Bangladesh owing to the political instability during the partition of Bengal and the liberation war of Bangladesh (1971) (Chatterjee, 1990). According to Som (1987), nearly six million refugees have arrived in West Bengal from East Pakistan in different waves up to 1971 and nearly 2 million have resided in Calcutta Municipal District Area in 1973 which constitutes almost $26 \%$ of the total population (CMDA, 1976).

Primary survey (2017) has revealed that a bulk of homeless people in Kolkata has arrived from the backward states like Bihar (37.18\%), 
Jharkhand (17.41\%), Uttar Pradesh (14.23\%) and Odisha (3.48\%) whereas only $2.53 \%$ of homeless people have migrated from other states of the country. On the contrary, $7.12 \%$ of homeless people have migrated from South 24 Parganas, followed by Murshidabad (5.38\%) and Paschim Medinipur (3.96\%). Rest 6.81\% has shifted from other districts of the state. Only three families comprising 13 members (occupying $1.90 \%$ of the respondents) were found in the station areas, who have originated from Bangladesh (Figure 13). Only $24.14 \%$ homeless households among them have migrated during the last 20 years, and rest of them live in the streets from 20 to 60 years. It has also been also found that $43.83 \%$ of the homeless people are born in the streets of the city, and don't have any connections with their native villages. The survey clearly reveals that the bulk of the homeless population of the city has originated from the less developed adjoining areas that serve as the source region. It has also been evident that the percentage of inter-state migrants is higher in the Barabazar area, whereas the Sealdah station area is primarily occupied by the intra-state migrants (Primary Survey, 2017).

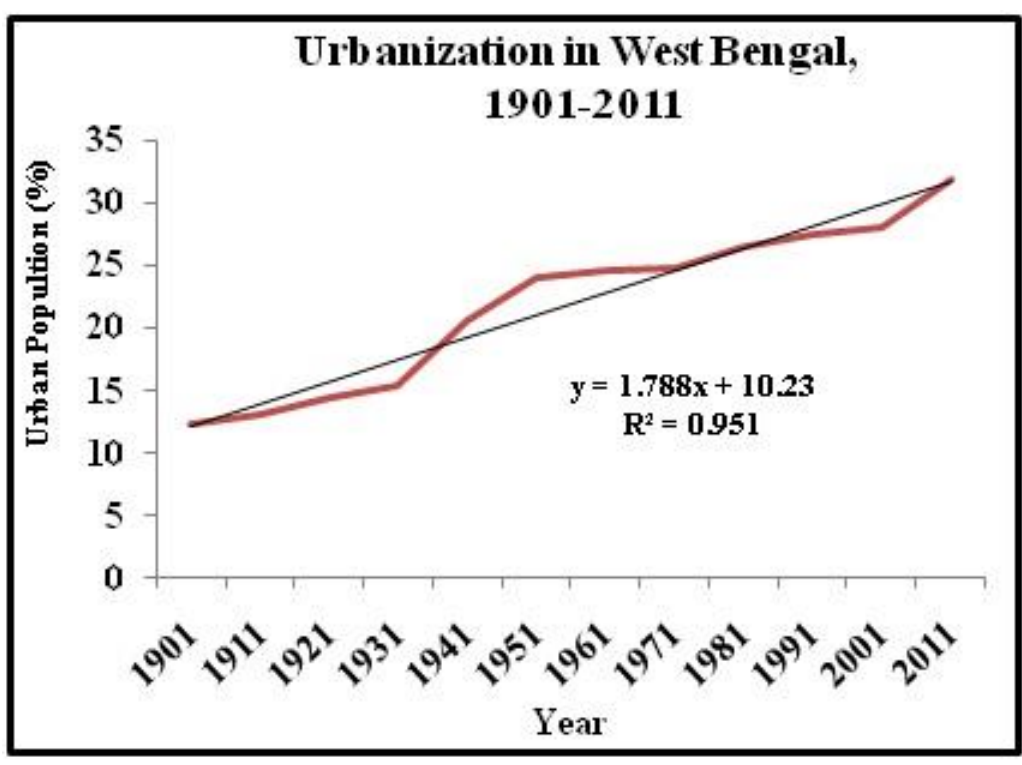

Figure 12

Data Source: Census of India, 1901-2011

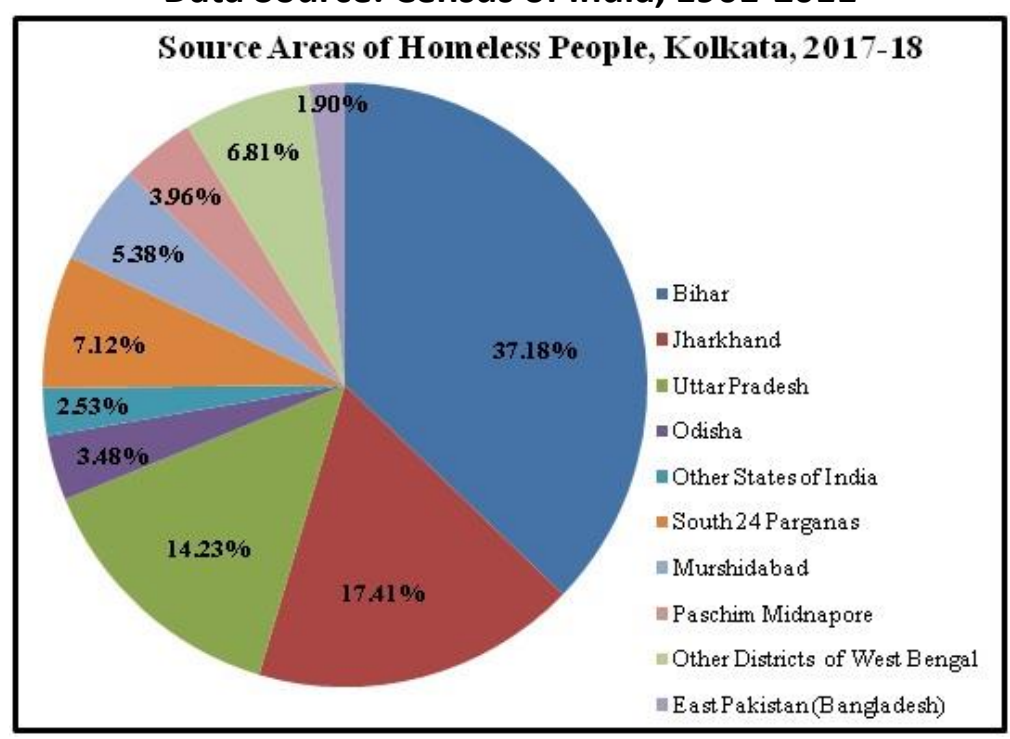

Figure 13

Data Source: Primary Survey, 2017-2018 
Local governance of the source region has failed to provide essential amenities to them for their continuation of life. As stated earlier, $89.72 \%$ of the respondents have migrated towards the city for economic purposes, with the aspiration of a better job, income and lifestyle (Primary Survey, 2017). Conversely, the Kolkata city generally dispenses opportunity of all sorts, from begging to scavenging, low paid jobs and even illegal works that support the minimum nutrition of the dwellers. Thus certain 'pull factors' have transmuted the city as the shelter (destination region) for the survival of rootless immigrants.

In many cases, the city with limited accommodation and infrastructural facilities, have failed to compensate the incoming immigrants. Moreover, those people have failed to get proper jobs and are incapable of affording a house for survival owing to their insufficient economic strength. Nearly, $97.15 \%$ of the respondents have reported their incapability to manage a shelter due to the lack of income. Only, $2.85 \%$ of the respondents have admitted that they can rent a home in sharing basis, but they are unwilling to expend any money for this purpose as they have to send the maximum share of the income to their families living in the native place. So, they prefer to spend their night under the open sky to minimise expenditure. Naturally, the footpaths of Kolkata metropolitan city have witnessed the assemblage of large quantities of homeless people, either single or with family, struggling to continue their life on the streets without security. A different trend of urbanisation has been observed during the last decade (2001- 2011) where the process of urbanisation began to spread into the interior districts away from Kolkata like Malda, Murshidabad, Nadia, Birbhum, Purulia and Jalpaiguri. Consequently, these districts have recorded higher growth rate of the urban population compared to highly urbanised districts of North 24 Parganas, Hugli and Bardhaman located around Kolkata (Chakraborty et al., 2015). The small and medium towns of the state have experienced lopsided immigration of rural people with varying magnitude. As a consequence, considerable population growth has occurred in the medium and small urban centres with the assemblage of 'sidewalk dwellers' in almost all cities or towns of the state. Naturally, the growth of urban population and urban homelessness has shown a positive relationship. Figure 14 has clearly shown the moderate correlation ( $r 2=0.407$ ) between the phenomenon of urbanisation and urban homelessness. It may be concluded that the gradual shifting of rural people towards the urban centres has positively influenced the urban homelessness scenario in the towns of West Bengal. Surprisingly, as an exception, Kolkata has shown negative growth $(-1.88 \%)$ in urban population during the last decades but has recorded an increasing trend in the homeless population (3.14\%). On the contrary, despite the fast rate of urbanisation (38\%), Darjeeling shows negative growth in concentration of urban homeless people ($54.9 \%)$.

It has been observed that inter-district disparity in the level of Human Development has close inter-linkages with the magnitude of homelessness. The district with higher HDI value has recorded a higher percentage of homeless people that have reflected the moderate positive correlation ( $r 2$ ) between the phenomenon of homelessness with the level of Human Development of the District (Figure 15). Spearman's Rank Correlation Coefficient is used as a method to compute the degree of association between $\mathrm{HDI}$ and concentration of the homeless population. The result shows that there is a moderate optimistic relationship between the $\mathrm{HDI}$ and homelessness of the districts (Table 4). To test the significance, Student's t-test has been computed with the help of following formula: $t=\sqrt{ } r 2(N-2) / 1-r 2$

The calculated t value scores to 1.96 , which is higher than the critical value of $t$ at 0.05 significance level with 17 degrees of freedom that is, 1.74 (one-tailed test). Thus, as t $0.05<1.96$ the value of $r$ is significant. 


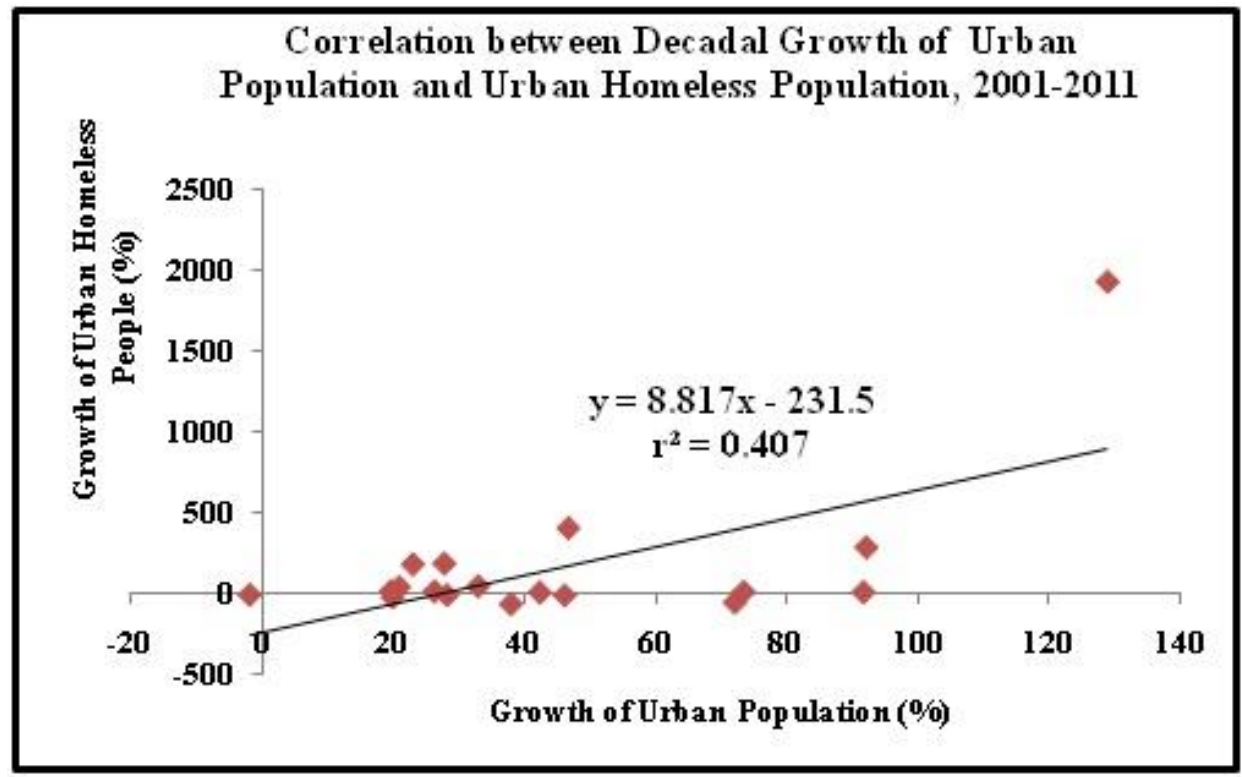

Figure 14: Correlation between Decadal Growth of Urban Population and Urban Homeless Population, 2001-2011

Data Source: Census of India, 2001-2011; Computed by the Authors

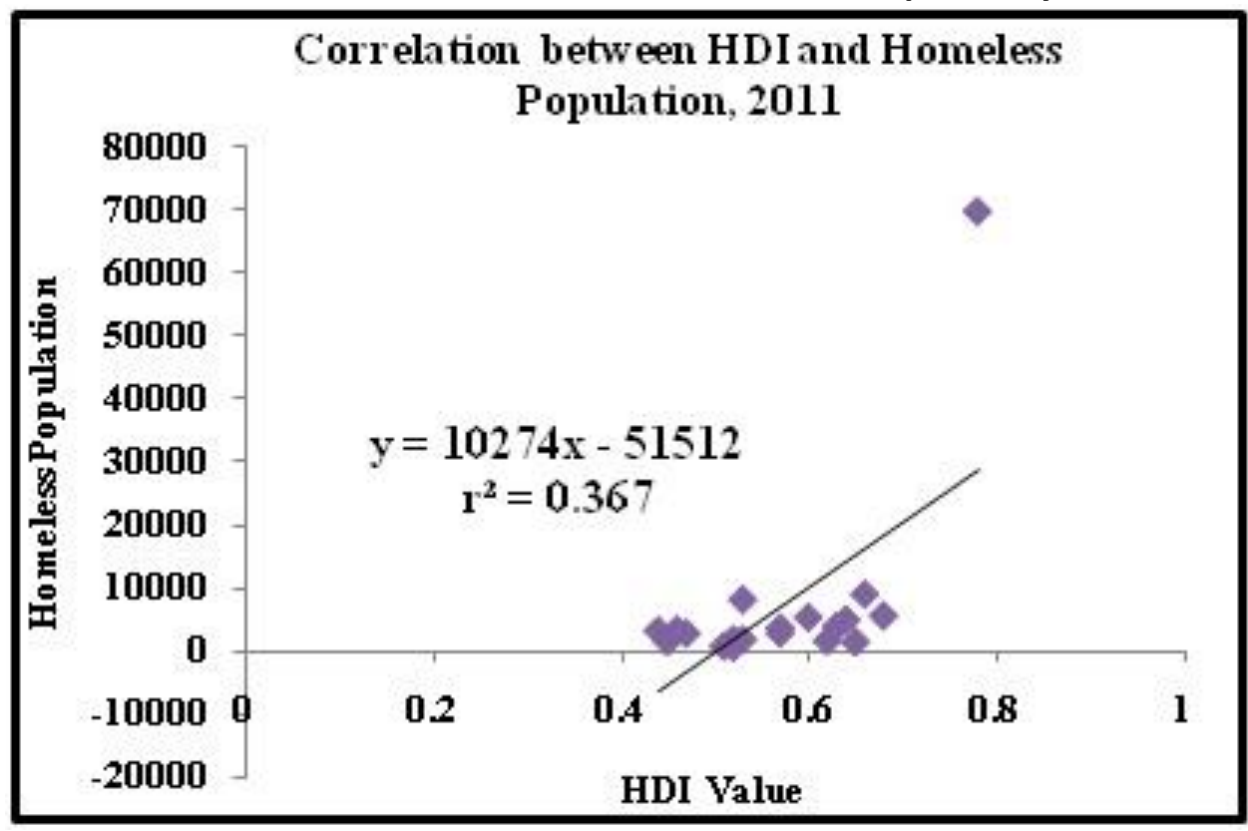

Figure 15: Correlation between HDI and Homeless Population, 2011

Data Source: Census and DHDR (2010-11)

It is accepted that the region with less HDI

(Human Development Index) generally have a considerable number of homeless population, but in reality, the situation is reverse. The movement of poor people from less developed areas (having low HDI value) towards the areas of better social and economic condition (having high HDI value) with the aspiration of a better lifestyle has explained the positive relationship. It may be said that the less developed areas (districts) have become the 'source areas' and have pushed a bulk of population towards the nearby towns without any security of food or shelter that generally increases the volume of homeless population in different pockets of the cities. The primary survey has pointed out that large share of the homeless population of Kolkata has come from South 24 Parganas (HDI Value 06), Murshidabad (0.46) and Paschim Midnapore (0.57) districts which has recorded much lower HDI value than Kolkata (0.78). 
Similarly, it is interesting to observe that the homelessness shows a moderate negative relationship with the poverty level of the districts of West Bengal (Figure 16). Poverty is one of the prime causes as well as the result of homelessness (Johnsen and Watts, 2014). It is a condition in which a person or community lacks the financial capacity and essentials to meet the basic needs to maintain a minimum standard of life and well-being normally followed in society. It deprives people of the freedom to decide over and shape their own lives (Tennerfeldt and Ljung, 2006). Poverty is viewed as a universal risk factor of homelessness, as "people who are not poor can usually avoid homelessness even if they experience personal crises" (Fitzpatrick et al. 2000: 28).

\begin{tabular}{ccccccc}
\hline \multicolumn{2}{c}{ Table 4: Calculation of Spearman's Rank Correlation Coefficient } \\
District & $\begin{array}{c}\text { HDI Value, } \\
\text { 2011 }\end{array}$ & Rank & $\begin{array}{c}\text { Homeless } \\
\text { Population, } \\
2011\end{array}$ & Rank & $\begin{array}{c}\text { Difference of } \\
\text { Rank (d) }\end{array}$ & d2 \\
\hline Malda & 0.44 & 1 & 3323 & 10 & 9 & 81 \\
\hline Purulia & 0.45 & 2 & 1587 & 4 & 2 & 4 \\
\hline Murshidabad & 0.46 & 3 & 3460 & 11 & 8 & 64 \\
\hline Birbhum & 0.47 & 4 & 2917 & 8 & 4 & 16 \\
\hline DakshinDinajpur & 0.51 & 5 & 868 & 2 & 3 & 9 \\
\hline Bankura & 0.52 & 6.5 & 1925 & 7 & 1.5 & 2.25 \\
\hline Cooch Behar & 0.52 & 6.5 & 700 & 1 & 5.5 & 30.25 \\
\hline Jalpaiguri & 0.53 & 8.5 & 1,924 & 6 & 2.5 & 6.25 \\
\hline Uttar Dinajpur & 0.53 & 8.5 & 8251 & 17 & 8.5 & 72.25 \\
\hline Nadia & 0.57 & 10.5 & 2957 & 9 & 1.5 & 2.25 \\
\hline PaschimMidnapur & 0.57 & 10.5 & 3768 & 12 & 1.5 & 2.25 \\
\hline South 24 Parganas & 0.6 & 12 & 5436 & 15 & 3 & 9 \\
\hline PurbaMedinipur & 0.62 & 13 & 1720 & 5 & 8 & 64 \\
\hline Hugli & 0.63 & 14 & 3969 & 13 & 1 & 1 \\
\hline Bardhaman & 0.64 & 15 & 5057 & 14 & 1 & 1 \\
\hline Darjeeling & 0.65 & 16 & 1559 & 3 & 13 & 269 \\
\hline North 24 Parganas & 0.66 & 17 & 9122 & 18 & 1 & 1 \\
\hline Haora & 0.68 & 18 & 5699 & 16 & 2 & 4 \\
\hline Kolkata & 0.78 & 19 & 69798 & 19 & 0 & 0 \\
\hline & & $\mathbf{\Sigma} \mathbf{d} \mathbf{2}$ & & & 638.5
\end{tabular}

Data Source: Census of India and DHDR (2010-11) ;Computed by the Authors Spearman's Rank Correlation Coefficient: $r=(A-B)+(A-C)-\sum d^{2} / 2 v(A-B)(A-C)=0.43$

The result of Spearman's rank correlation coefficient $(r=-0.47)$ shows that there is a moderate inverse relationships between the poverty level and homelessness scenario of the districts (Table 5). The calculated t value scores to2.13, which is higher than the critical value of $t$ at 0.05 significance level with 17 degrees of freedom, that is, 1.74 (one-tailed test). Thus, as t0.05 is far less than 3.43 the correlation is significant. The relationship may be analysed with the help of the phenomenon of migration. Poor areas (with high Human Poverty Index value) have pushed the insolvent people to move towards the areas with low HPI value. The gradual shifting of insolvent people towards the areas of less poverty has lowered 
down the figure of homeless people in the impoverished region and boosts the volume of homeless people in the comparatively more affluent urban areas (destination region). The primary survey has revealed that the relatively poor neighbouring states like Bihar, Jharkhand have contributed the large share of the homeless population of Kolkata. In case of intra-district scenario, the relatively poor districts like South 24 Parganas (HPI Value 41), Murshidabad (47.4), etc. have acted as the source areas of homeless people, who have been accumulated in the district (city) of Kolkata, which has recorded much lower HDI value than Kolkata (0.78).

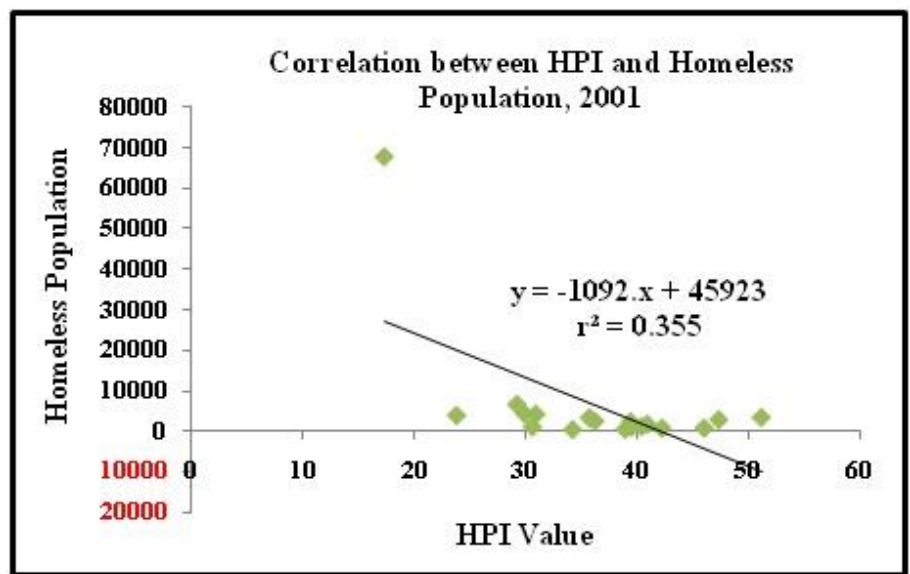

Figure 16

Data Source: Census of India, 2001 and WBDR, 2010

\section{Table 5: Calculation of Spearman's Rank Correlation Coefficient}

District

Homeless Population, 2001

Rank

HPI Value, 2001

Rank Difference of $\mathrm{d} 2$

Rank (d)

\begin{tabular}{|c|c|c|c|c|c|c|}
\hline Bankura & 535 & 1 & 34.3 & 6 & 5 & 25 \\
\hline DakshinDinajpur & 617 & 2 & 39 & 9 & 7 & 49 \\
\hline Koch Bihar & 868 & 3 & 42.3 & 14 & 11 & 121 \\
\hline Maldah & 889 & 4 & 46.1 & 15 & 11 & 121 \\
\hline Purulia & 1126 & 5 & 39.6 & 11 & 6 & 36 \\
\hline Nadia & 1173 & 6 & 30.7 & 4 & 2 & 4 \\
\hline Birbhum & 1272 & 7 & 40.5 & 12 & 5 & 25 \\
\hline South 24 Parganas & 1861 & 8 & 41 & 13 & 5 & 25 \\
\hline Medinipur & 2460 & 9 & 39.5 & 10 & 1 & 1 \\
\hline Jalpaiguri & 2637 & 10 & 36.3 & 8 & 2 & 4 \\
\hline Murshidabad & 2995 & 11 & 47.4 & 16 & 5 & 25 \\
\hline Darjeeling & 3431 & 12 & 35.8 & 7 & 5 & 25 \\
\hline Uttar Dinajpur & 3531 & 13 & 51.2 & 17 & 4 & 16 \\
\hline Hugli & 4043 & 14 & 23.9 & 1 & 13 & 269 \\
\hline Bardhaman & 4300 & 15 & 31 & 5 & 10 & 100 \\
\hline Haora & 4404 & 16 & 30 & 3 & 13 & 269 \\
\hline North 24 Parganas & 6717 & 17 & 29.3 & 2 & 15 & 225 \\
\hline Kolkata & 67676 & 18 & 17.4 & 0 & 0 & 0 \\
\hline
\end{tabular}

Data Source: Census of India, 2001 and WBDR, 2010(Computed by the Authors)

Spearman's Ranking Correlation Coefficient: $r=1-6 * \sum d^{2} / N^{3}-N=-0.47$ 


\section{Conclusion}

Homelessness depicts the most apparent and severe manifestation of denial of the human rights to adequate housing. The maximum concentration of poor and homeless human groups is evident in Kolkata as it extends them the provisions of earning for survival. It has been revealed in the analysis that the main factors for leaving their roots have been multifarious, but economic factors are most dominant. Lopsided development in the urban areas and relatively less development in the source areas have attracted the jobless, homeless people to the towns and cities. Besides social isolation or marginalisation and political instability in source areas, the destruction of habitats and sources of livelihood by natural calamities pushed the poor rural folks towards the nearby urban areas (especially towards Kolkata). Thus, the city has evidenced the booming of homeless people, whereas, the rural homelessness has recorded a declining trend.

The economic and socio-political reasons for leaving the rural roots and migrating to the urban pockets are still active in the source areas of migration. Thus, assurance of socioeconomic and political security along with self-provisioning in those source regions may be a suitable policy to reduce the flow of the uprooted migrants.

\section{References}

Adhikari, H. (2014). Living Status/Shelter of Street Families of Kolkata: Prospects and Challenges. Open Access Library Journal, 1(571), (http://dx.doi.org/10.4236/oalib.1100571)

Ali, M. (2012).Socio-Economic Analysis of Homeless Population in Urban Areas a Case Study of Northern Ethiopia. International Journal of Scientific and Research Publications, 2(8): 1-7

Ali, M. (2014).Status of Homeless Population in Urban Ethiopia: A Case Study of Amhara Region. International Journal of Management and Social Sciences Research 3(1): 61-68

Allred, J. (2006). Homeless Housing Plan for Davis County, Wasatch Front Regional
Council, State of Utah, Department of Community and Culture.

Anisujjaman, Md. (2015). Urbanisation and Human Development: A Study of West Bengal. International Journal of Humanities and Social Science Invention, 4(7): 1-8.

Bagchi, D. (2016). Street Dwelling and City Space: Women Waste Pickers in Kolkata. Economic and Political Weekly, II (26/27): 6368.

Baker, R., Panter-Brick, C. and Todd, A. (1997). Homeless Street Boys in Nepal: Their Demography and Lifestyle, Journal of Comparative Family Studies, 28(1), 129-146.

Basu, S. (2016). Quality of Life among the Pavement Dwellers in KMDA. Indian Journal of Landscape System and Ecological Studies, 39(2): 271-280.

Bharati, S. B. (1999). Human Rights and Development Projects in India, The PRP Journal of Human Rights, 3 (4).

Bhattacharya, B. (1996). Slums and Pavement Dwellers of Calcutta Metropolis. Kolkata: Aparna Book Distributors

Bhattacharya, B. (2012). Homeless Pavement Dwellers: A Case Study of their Social Awareness in Kolkata from Human Rights Perspective, Journal of Exclusion Studies, 2(1): 10-29.

Brandon, D., K. Wells, C. Francis and E. Ramsey, (1980). The Survivors: A Study of Homeless Young Newcomers to London and the Responses Made to them. London: Routledge/Kegan Paul.

Busch-Geertsema, V., Culhane, D., and Fitzpatrick, S. (2016). Developing a Global Framework for Conceptualising and Measuring Homelessness. Habitat International 55, 124-132.

BBC News (2018, October 10). Single mothers 'hit hard by homelessness. Retrieved from https://www.bbc.com/news/uk-45800186

Calcutta Metropolitan Development Authority. (1976). Calcutta Metropolitan District- Some 
facts and Figures, Government of West Bengal

Census of India (1961 to 2011), Government of India

Chakraborty, S., S. Chatterjee, K. Das and U. Roy, (2015).Changing Pattern of Urbanization in West Bengal: An Analysis of 2011 Census of India Data. Asian Journal of Research in Social Sciences and Humanities, 5(5): 169-181.

Chatterjee, N. (1990). The East Bengal Refugees

A Lesson in Survival. In Chaudhuri S, (Ed.) Calcutta: A Living City: The Present and Future (Vol. 2). Calcutta: Oxford University Press.

Chaudhuri.S. (2013). Living at the Edge: A SocioEconomic Profile of Kolkata's Poor. South Asian Survey, 20(1): 44-58.

Chauhan, S. (2009). Climate Change, Disasters and Security - Issues, Concerns and Implications for India, Paper presented to KDI conference, Seoul, June 12th, 2009. http://www.welfareacademy.org/.../Climate\%2 0Change,\%20Disasters\%20and\%20Security\%20Implications\%20for\%20India Accessed on October 03, 2017

Das, A. (2013). Demography, Migration and Economic Status of Pavement Dwellers - A Study of Most Marginalized Urban Poor in Central Business Areas of Kolkata, West Bengal. International Journal of Science and Research, 4 (7): pp. 1496-1501.

Dey, F. and K. K. Majumdar (2015). Pavement Dwellers in Kolkata: Issues and Challenges. Researchers World, VI (2.2): 1-13.doi: 10.5958/2249-7315.2015.00117.3

Dupont, V., E. Tarlo and D. Vidal (2000) Delhi: Urban Space and Human Destinies New Delhi: Manohar Publications

Fernandes, W. (2007).Singur and the Displacement Scenario, Economic and Political Weekly, 203-206

Fernandes, W., S. Chhetri, S. Joseph and S. Lama (2006). Development-Induced Displacement and Deprivation in West Bengal 1947-2000: A Quantitative and Qualitative Database on Its
Extent and Impact. Guwahati: North Eastern Social Research Centre

Fitzpatrick, S., P. Kemp and S. Klinker (2000). Single Homelessness: An Overview of Research in Britain. Bristol: The Policy Press.

Ghosh, B., and N. Chakma (2014). Urbanisation in West Bengal: An Analysis of Recent Processes, Space and Culture, India, 2(2): 28-41, https://doi.org/10.20896/saci.v2i2.86

Ghosh, R. (2014). Problems of Pavement dwellers of Kolkata. Indian Journal of Landscape System and Ecological Studies, International Seminar Volume

Giri, P. (1998). Urbanisation in West Bengal, 1951-1991, Economic and Political Weekly, 33(47/48): 3033-3038.

Government of India (1985): Report of the Committee on Rehabilitation of Displaced Tribals Due to Development Projects, Ministry of Home Affairs, New Delhi.

Government of India (2013). Reference Note on Displacement and Rehabilitation of People Due to Developmental Projects (No. 30/RN/Ref./December/2013). Lok Sabha, New Delhi, India.

Government of India (2016). The Homeless Pavement Dwellers (Welfare) Bill, 2016 (Bill No. 10 of 2016), Lok Sabha, New Delhi, India.

Gowan, T. (2010). Hobos, Hustlers and Backsliders: Homeless in San Francisco. Minneapolis, MN: University of Minnesota Press.

Heinze, H. J., Jozefowicz, D. M. H., Toro, P. A. and Blue L. R. (2012) Reasons for Homelessness: An Empirical Typology, Vulnerable Children and Youth Studies, 7:1, 88101, doi: 10.1080/17450128.2011.643832

Jagannathan, N. V., and A. Halder (1988). A Case Study of Pavement Dwellers in Calcutta: Occupation, Mobility and Rural-Urban Linkages. Economic and Political Weekly, 23(49): 26022605.

Jagannathan, N. V., and A. Halder (1988). Income-Housing Linkages: A Case Study of 
Pavement Dwellers in Calcutta. Economic and Political Weekly, 23(23): 1175-1178.

Jagannathan, N. V., and A. Halder (1989). A Case Study of Pavement Dwellers in Calcutta: Family Characteristics of the Urban Poor. Economic and Political Weekly, 24(6): 315-318.

Jegede, A. (2018, July 2). Top 13 Cities With Highest Homeless Population In The World. Retrieved from https://www.trendrr.net/13046/top-citieswith-highest-homeless-population-worldfamous-lowest/

Johnsen, S. and Watts, B. (2014). Homelessness and Poverty: Reviewing the Links. Paper presented at the European Network for Housing Research (ENHR) conference, Edinburgh,1-4 July 2014 (http://www.jrf.org.uk/topic/anti-poverty)

Kar, S. (2016). Pavement Dwellers of Central Kolkata: A Critical Analysis. Golden Geographer, I: 85-90.

Khatun, S., Das, S. and Pal, S. (2018). Exploring the Ambient Environment for Charland Formation in Rajmahal Downstream Ganga River of Eastern India in Post Farakka Barrage Period.Spatial Information Research.doi: 10.1007/s41324-018-0179-x

Koehlmoos, T. P., Jasim Uddin, M., Ashraf, A. and Rashid. M. (2009). Homeless in Dhaka: Violence, Sexual Harassment, and Drug-abuse. Journal of Health, Population and Nutrition, 27(4), 452-461.

Kumuda, D. (2014). Homeless Population in India: A Study. Global Journal for Research Analysis, 3(8): 54-55.

Lipton, F. R., and A. Sabatini (1984).Constructing Support Systems for Homeless Chronic Patients and the Homeless Mentally III: A Task Force Report of the American Psychiatric Association, American Psychiatric Association, Washington D. C.

May, J. (2000). Housing Histories and Homeless Careers: A Biographical Approach. Housing Studies, 15 (4): pp. 613-638.
Morrow, S. (2010). The Homeless in Historical Context, Development Southern Africa, 27(1): 51-62. doi: 10.1080/03768350903519341

Mostowska, M. (2013) Migration and Homelessness: The Social Networks of Homeless Poles in Oslo, Journal of Ethnic and Migration Studies, 39:7, 1125-1140, doi: 10.1080/1369183X.2013.778037

Mukherjee, S. (1975). A Report on the Survey of 10000 Pavement Dwellers in Calcutta, under the shadow of the Metropolis They are Citizens too, Calcutta Metropolitan Development Authority, Kolkata

Mukhopadhyay A., Dutt A.K., Haldar A. (1994) Sidewalk Dwellers of Calcutta. In: Dutt A.K., Costa F.J., Aggarwal S., Noble A.G. (eds) The Asian City: Processes of Development, Characteristics and Planning. The Geo Journal Library, 30.Springer, Dordrecht.

https://doi.org/10.1007/978-94-011-10020_22

Mustaquim, M., and M. Ismail (2013).An Analysis of the Socio-Economic Conditions of Homeless Population in parts of Kolkata, West Bengal, India. Indian Journal of Spatial Science, 4.0(2): $43-51$.

Nooe, R. M., and D. A. Patterson (2010). The Ecology of Homelessness, Journal of Human Behavior in the Social Environment, 20: 105152.

Patel, S.(1990). Street Children, Hotel Boys and Children of Pavement Dwellers and Construction workers in Bombay- How They Meet Their Daily Needs. Environmrnt and Urbanization, 2(2), 9-26.

Patra, S., and K. Anand (2008). Homelessness: A Hidden Public Health Problem. Indian Journal of Public Health, 52 (3): 164-170.

Pleace, N. (2000). The New Consensus, the Old Consensus and the Provision of Services for People Sleeping Rough. Housing Studies, 15 (4): 581-594.

Roy Chowdhury, M. (1999). Slum and Pavement Dwellers of Calcutta: A Geographical Analysis. 
Unpublished Doctoral Thesis, The University of Burdwan

Ryabchuk, A. (2014). Homelessness in Ukraine:

Structural Causes and Moral Evaluation, Debatte: Journal of Contemporary Central and Eastern Europe, 22(3): 288-306. doi:10.1080/0965156X.2014.988964

Sattar, S. (2014), Homelessness in India, Shelter, 15 (1): 9-15.

Seshadri, K. R. (2008). When Home is a Camp: Global Sovereignty, Biopolitics and Internally Displaced Persons. Social Text 94 26(1): 29-54.

Sivaramakrishnan, L., and P. Mondal (2014). The Invisible Population in Indian Cities. Eastern Geographer, XX (1): 251-258.

Som, N. (1987). Bustees, Pavement Dwellers and Refugees of Calcutta. In Pradip Sinha, (Ed.) The Urban Experience Kolkata, Kolkata: Riddhi.

Somerville, P. (2013). Understanding Homelessness. Housing, Theory and Society, 30(4): pp. 384-415. doi: 10.1080/14036096.2012.756096

SPARC (1985). http://www.sparcindia.org/pdf/articles/invisre v.pdf Retrieved June 2, 2017, from http://www.sparcindia.org

Speak,S. (2004). Degrees of Destitution: A Typology of Homelessness in Developing Countries, Housing Studies, 19:3, 465-482, doi:10.1080/0267303042000204331

Springer, S. (2000). Homelessness: A Proposal for a Global Definition and Classification. Habitat International, 24(4): pp. 475- 484.

Tannerfeldt G. and P. Ljung (2006). More Urban, Less Poor: An Introduction to Urban Development and Management, London and New York: Routledge.

Tipple, G. and Speak, S. (2004). Attitudes to and Interventions in Homelessness: Insights from an International Study. International Conference on Adequate and Affordable Housing for all: Research, Policy, Practice, 24-27 June, 2004, Toronto
Tribhuvan, R. D., and R. Andreassen (2003). Streets of Insecurity: Study of Pavement Dwellers in India. New Delhi: Discovery Publishing House.

Tripathi, S. (2017).Development, Displacement and Human Rights Violations. Indian Journal of Public Administration 63(4) 567-578. doi: 10.1177/0019556117726821

Ullah, A.K.M.A., A. Rahaman, and M. Murshed (1999). Poverty and Migration: Slums of Dhaka City: The Realities, Association for Rural Development and Studies, Dhaka, Bangladesh.

UNDP (2009), Situation Report - Cyclone Aila 27 May 2009.

United Nations Centre for Human Settlements (Habitat) (2000).Strategies to Combat Homelessness.Nairobi, Retrieved June 7. 2018, fromhttp://www.unchs.org

United Nations Human Settlements Programme (2015). Un-Habitat Global Activities Report 2015, Increasing Synergy for Greater National Ownership, United Nations.

Universal Declaration of Human Rights (UDHR) (2015). UNO, Retrieved June 2. 2018, from http://www.un.org/en/udhrbook/pdf/udhr_bo oklet_en_web.pdf

Vázquez, C., Muñoz, M., Crespo, M., Guisado, A. B., and Dennis, M. L. (2005). A Comparative Study of the Twelve-Month Prevalence of Physical Health Problems among Homeless People in Madrid and Washington, D.C. International Journal of Mental Health, 34(3), Homelessness and Health (II). pp 35-56.

Wardhaugh, J. (2012), Rural Homelessness in India. In S. J. Smith (Ed.) International Encyclopedia of Housing and Homelessness. Retrieved on June 2. 2018, from https://www.elsevier.com/books/international -encyclopedia-of-housing-andhome/smith/9780-08-047163-1

Warnes A. M. and Crane, M. (2006). The Causes of Homelessness among Older People in England. Housing Studies 21(3), pp. 401-421, doi: 10.1080/02673030600586027 
Yonge, Y. (2007). United States Hunger and Homeless Survey: A Status Report on Hunger and Homelessness in America's Cities. In E.A.
Michael (Ed.), Homeless and Shelter, New York: Orlando Sentinel. 